Tropical Journal of Pharmaceutical Research January 2019; 18 (1): 203-209

ISSN: $1596-5996$ (print); 1596-9827 (electronic)

(c) Pharmacotherapy Group, Faculty of Pharmacy, University of Benin, Benin City, 300001 Nigeria.

Available online at http://www.tjpr.org

Original Research Article

http://dx.doi.org/10.4314/tjpr.v18i1.30

\title{
Utilization of Bridelia mollis as herbal medicine, nutraceutical and functional food in southern Africa: A review
}

\author{
Alfred Maroyi \\ Medicinal Plants and Economic Development (MPED) Research Centre, Department of Botany, University of Fort Hare, Private \\ Bag X1314, Alice 5700, South Africa
}

*For correspondence: Email: amaroyi@ufh.ac.za; Tel: 0027719600326

Sent for review: 16 May 2018

Revised accepted: 12 December 2018

\begin{abstract}
Purpose: To evaluate the functional food, nutraceutical and ethnomedicinal properties of Bridelia mollis throughout its geographical range.

Methods: Retrieval of information on the medicinal, nutraceutical and functional food properties of $B$. mollis was undertaken using electronic databases, including PubMed, EThOS, ScienceDirect, SCOPUS, ProQuest, SciFinder, Medline, Open-thesis, OATD and Google Scholar. Pre-electronic literature was sourced from the University library.

Results: Literature search revealed that fresh or dried fruits of $B$. mollis can be commercially processed into new food products and beverages in southern Africa. Bridelia mollis is traditionally used as herbal medicine for cough, itching, fever, gastro-intestinal problems, malaria, piles, parasitic worms and wounds. Pharmacological studies on B. mollis indicate that the species has antibacterial, antifungal, antileishmanial, antioxidative and antiplasmodial properties.

Conclusion: Detailed studies on the phytochemistry, pharmacological and toxicological properties of $B$. mollis are needed in order to establish the real nutraceutical potential benefits of the species that might improve human health.
\end{abstract}

Keywords: Antibacterial, Antifungal, Antileishmanial, Antioxidative, Antiplasmodial, Bridelia mollis, Phyllanthaceae

\begin{abstract}
This is an Open Access article that uses a funding model which does not charge readers or their institutions for access and distributed under the terms of the Creative Commons Attribution License (http://creativecommons.org/licenses/by/4.0) and the Budapest Open Access Initiative (http://www.budapestopenaccessinitiative.org/read), which permit unrestricted use, distribution, and reproduction in any medium, provided the original work is properly credited.
\end{abstract}

Tropical Journal of Pharmaceutical Research is indexed by Science Citation Index (SciSearch), Scopus, International Pharmaceutical Abstract, Chemical Abstracts, Embase, Index Copernicus, EBSCO, African Index Medicus, JournalSeek, Journal Citation Reports/Science Edition, Directory of Open Access Journals (DOAJ), African Journal Online, Bioline International, Open-J-Gate and Pharmacy Abstracts

\section{INTRODUCTION}

Bridelia mollis Hutch. (Figure 1), family Phyllanthaceae has tremendous potential as herbal medicine, nutraceutical agent and functional food mainly due to its medicinal and nutritional properties. Bridelia mollis is native to Malawi, Botswana, Zimbabwe, South Africa, Namibia, Zambia and Mozambique [1-3]. The fruits are edible, make useful jam and other beverages used by households throughout the geographical range of the species [1,3-9]. The fruit contains a hard seed, surrounded by a thin layer of pulp and its taste and flavour has been compared to that of prune (Prunus domestica L.) by Palmer and Pitman [3]. The pressed fruits exude a clear gum which is used to make jam or 
juice throughout the distributional range of the species in Southern Africa.

Previous research by Van Wyk [10] showed that the dried and fresh fruits of $B$. mollis can be commercially processed into new food products and beverages such as jam, juice and other processed products. The leaves, fruits and twigs of $B$. mollis are excellent fodder for livestock and game in southern Africa [11,12]. There are several research projects [13-15] attempting to characterize the phytochemical, pharmacological and nutraceutical properties of the species. There has been an increase in the demand for nutraceuticals and functional foods over the years due to the growing concern of society for health and quality of life [16-18]. Rivera et al [16] defined functional foods as food sources that have positive physiological properties that are beyond their nutritional uses of providing essential nutrients. While Varzakas et al [19] defined nutraceutical as any food source or supplementary diet that provides a concentrated form of a pharmacologically active component of food in a non-food form to improve human health.

Rivera et al [16] argued that nutraceutical agents with commercial value can be generated from functional foods which have demonstrated phytochemical and pharmacological properties that are able to protect humans against chronic or infectious diseases. According to the nutraceutical and nutritional therapy theory [17], beneficial nutrients and phytochemical compounds are provided by the nutraceuticals which detoxify the entire human body, supplementing vitamins and essential minerals, resulting in the restoration of a healthy digestion and dietary habit. Research on indigenous edible fruits as possible sources of nutraceuticals is associated with opportunities for using innovative technologies for bioprospecting and the development of pharmaceutical drugs and health products. It is within this context that ethnopharmacological and nutraceutical review of the species was carried out aimed at understanding the medicinal and functional value of $B$. mollis.

\section{METHODS}

Information on the food value, ethnomedicinal and nutraceutical properties of $B$. mollis was retrieved from September 2017 to March 2018. Online electronic databases such as Pubmed, EThOS, ScienceDirect, SCOPUS, ProQuest, SciFinder, Medline, Open-thesis, OATD and Google Scholar were used to search for relevant literature. Pre-electronic literature sources included conference papers, books, scientific articles, book chapters, theses and dissertations obtained from the University of Fort Hare library.

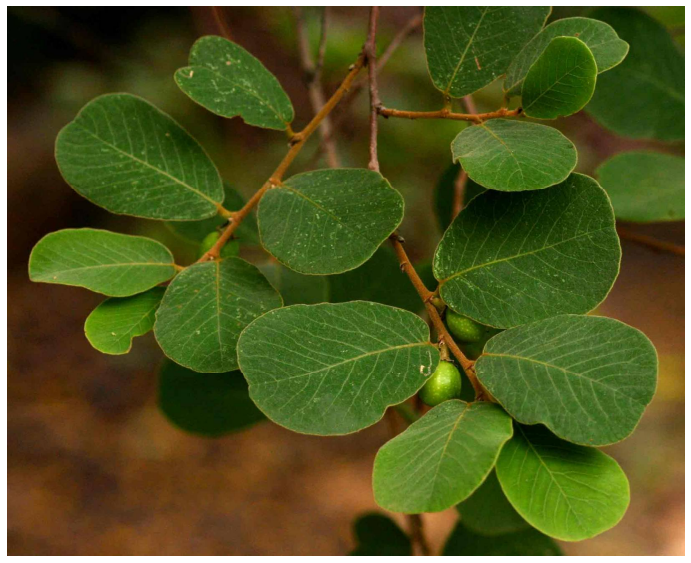

Figure 1: Bridelia mollis: a branch showing leaves and fruits (photo: BT Wursten)

The keywords used in the search included "Bridelia mollis", the synonyms of the species "Bridelia scandens sensu Eyles and Bridelia schlechteri Hutch." English common names "bushveld bridelia, velvet sweetberry and velvetleaved bridelia". The following combination of keywords was used to search for relevant information: "biological properties + Bridelia mollis", "ethnobotany + Bridelia mollis", "ethnomedicinal uses + Bridelia mollis", "ethnopharmacological properties + Bridelia mollis", "food uses or values + Bridelia mollis", "medicinal uses + Bridelia mollis", "nutraceutical properties + Bridelia mollis", "pharmacological properties + Bridelia mollis" and "phyochemistry + Bridelia mollis". A total of 44 articles published between 1972 and 2018 were in agreement with the literature search criteria (Figure 1). The sources of data included research articles results published in scientific journals (29), books (seven), theses and dissertations (five), book chapter and website (one each).

\section{FINDINGS AND DISCUSSION}

\section{Botanical profile of Bridelia mollis}

Bridelia mollis Hutch. is a deciduous shrub or a small tree of the Phyllanthaceae family (previously included in the Euphorbiaceae family). The name of the genus, "Bridelia" was derived from the name of a Swiss-German muscologist, Samuel Elisée Bridel-Brideri (17611828) $[3,20,21]$. The specific epithet "mollis" means "soft", alluding to the characteristic velvety leaves of the species [2,3,22]. 


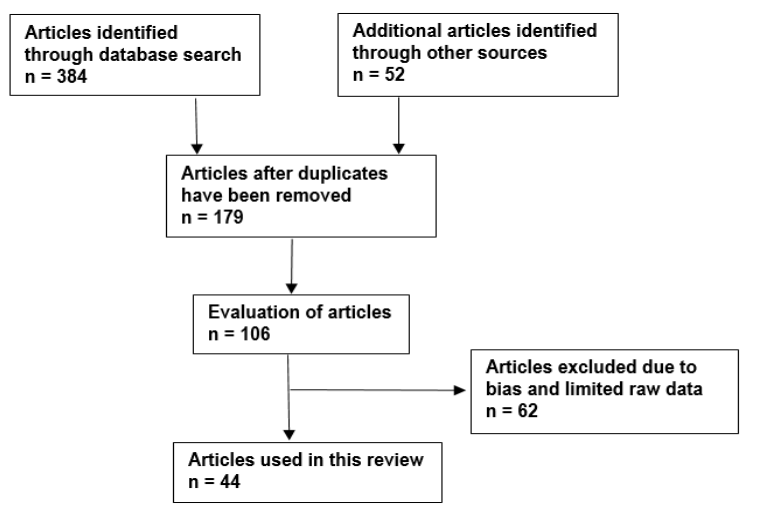

Figure 1: Flow diagram showing literature search results and selection processes

The Phyllanthaceae family was a sub-family of Euphorbiaceae until Hoffmann et al [23] separated the two families based on molecular studies using DNA sequence data of nuclear PHYC and plastid atpB, matK, ndhF and rbcL in conjunction with morphological characters. The synonyms of $B$. mollis include Bridelia scandens sensu Eyles and Bridelia schlechteri Hutch. and English common names include bushveld bridelia, velvet sweetberry and velvet-leaved bridelia.

Globally, the family has 59 genera and 2000 species [23]. Bridelia is a genus of about 60 to 70 species that have been recorded in tropical and subtropical Africa and Asia [21,24,25]. Bridelia mollis is a small deciduous tree or shrub growing not more than $8 \mathrm{~m}$ in height [3]. Bridelia mollis has a small spreading and well-branched crown growing on dark brown to grey stem with rough and longitudinal striations [3,26]. The leaves are alternate, entire, ovate to obovate in shape, light green in colour and densely velvety on both surfaces. The lateral veins on leaves are prominent below and terminating at the leaf margin $[1,3,26]$. Flowers of $B$. mollis are very small, occur in tight axillary clusters, greenishyellow in colour and unisexual on the same tree. The fruit is a subspherical fleshy berry, green when immature, and turning black when mature, edible and made into jam and beverages throughout the distribution of the species [1-9]. The fruits remain on the tree after the leaves have fallen off. The species has been recorded near streams, on rock outcrops and hills and at an altitude ranging from 200 to $1525 \mathrm{~m}$ above sea level $[1-3,22,26]$.

\section{Medicinal uses of Bridelia mollis}

In Botswana, root decoction of $B$. mollis is taken orally as remedy for diarrhoea [27] and the leaves are boiled and the solution rubbed on the body as a soothing lotion [22]. In South Africa, leaf infusion is applied topically for burning sensation, itching and wounds [28]. According to Mabogo [28], leaf root decoction of $B$. mollis is taken orally as emetic, and remedy for dysentery and piles in Venda, the Limpopo province, South Africa.

Research by Bapela [29] showed that root decoction of $B$. mollis is taken orally as remedy for fever, malaria and parasitic worms in South Africa. Research by Arnold and Gulumian [30] and Bapela [29] showed that roots of $B$. mollis are taken orally mixed with roots of Trichilia emitica Vahl as remedy for parasitic worms in Venda region of the Limpopo province in South Africa. In Zimbabwe, root decoction of $B$. mollis is taken by mouth as remedy for cough [31] and stomach pains while leaf infusion is applied topically for black blisters or skin blisters [4]. A closely related species, $B$. micrantha (Hochst.) Baill. is also used as herbal medicine against diarrhoea, parasitic worms and wounds in South Africa [20], cough, dysentery, fever and malaria in the Democratic Republic of Congo [32].

Table 1: Medicinal applications of Bridelia mollis in southern Africa

\begin{tabular}{|c|c|c|c|}
\hline Medicinal use & Plant part used & Country & Reference \\
\hline Burning and itching & Leaves infusion applied topically & South Africa & 28 \\
\hline Cough & Root infusion taken orally & Zimbabwe & 31 \\
\hline Diarrhoea & Root infusion taken orally & Botswana & 27 \\
\hline Dysentery & Leaf infusion taken by mouth & South Africa & 28 \\
\hline Emetic & Leaf infusion taken by mouth & South Africa & 28 \\
\hline Fever & Root decoction taken by mouth & South Africa & 29 \\
\hline Malaria & Root infusion taken by mouth & South Africa & 29 \\
\hline Parasitic worms & $\begin{array}{l}\text { Roots taken orally mixed with Trichilia emitica } \\
\text { Vahl }\end{array}$ & South Africa & 29,30 \\
\hline Parasitic worms & Root infusion taken by mouth & South Africa & 29 \\
\hline Piles & Leaf decoction taken orally & South Africa & 28 \\
\hline Skin blisters & Leaf infusion applied topically & Zimbabwe & 4 \\
\hline Soothing lotion & Leaf decoction rubbed on the body & Botswana & 22 \\
\hline Stomach pains & Root decoction taken orally & Zimbabwe & 4 \\
\hline Wounds & Leaf infusion applied topically & South Africa & 28 \\
\hline
\end{tabular}


Pharmacological properties of Bridelia mollis

Traditional uses of $B$. mollis as herbal medicine encouraged researchers to evaluate antibacterial [33], antifungal [34,35], antileishmanial [14,36], antioxidative [13,37], antiplasmodial [38] and cytotoxicity $[14,36,38]$. Some of the documented biological activities may justify some of the medicinal uses of the species or may provide insight into the therapeutic potential of $B$. mollis.

\section{Antibacterial activity}

Shai et al [33] assessed antibacterial properties of acetone, dichloromethane and methanolic leaf extracts of Bradelia mollis against Staphylococcus epidermidis, Bacillus cereus, Citrobacter fruendii, Enterobacter aerogenes, Bacillus stearothermophilus, Enterococcus faecalis, Escherichia coli, Klebsiela oxytoca, Klebsiela pneumonia, Lactobacillus acidophilus, Micrococcus luteus, Proteus mirabilis, Proteus vulgaris, Pseudomonas aeruginosa, Serratia marcescens, Pseudomonas fluorescens, Salmonella typhi, Staphylococcus aureus, and Streptococcus pyogenes using serial microplate dilution method with gentamicin as positive control. The extracts exhibited activities with minimum inhibitory concentration (MIC) values ranging from $0.31 \mathrm{mg} / \mathrm{mL}$ to $>2.5 \mathrm{mg} / \mathrm{mL}$. The average total activity of the extracts ranged from $20.0 \mathrm{~mL} / \mathrm{g}$ to $313 \mathrm{~mL} / \mathrm{g}$ [33]. These antibacterial evaluations done so far corroborate use of $B$. mollis as traditional medicine against diarrhoea in Botswana [27], dysentery and wounds in South Africa [28].

\section{Antifungal activity}

Samie et al [34] assessed antifungal activities of acetone and hexane leaf extracts of $B$. mollis against Cryptococcus neoformans, Candida krusei and Candida albicans isolated from acquired immunodeficiency syndrome (AIDs) patients using agar diffusion and the microdilution methods with nystatin $(10 \mu \mathrm{l})$ and flourocystosine $(10 \mu \mathrm{l})$ as positive controls. The hexane extract showed activities against Cryptococcus neoformans with $7 \mathrm{~mm}$ zone of inhibition which was comparable to $22 \mathrm{~mm}$ zone of inhibition exhibited by both controls, nystatin and flourocystosine. The MIC values of hexane and acetone extracts against all the pathogens ranged from $3.75 \mathrm{mg} / \mathrm{mL}$ to $>7.5 \mathrm{mg} / \mathrm{mL}$ [34]. Mukanganyama et al [35] assessed antifungal activities of bark and leaf ethanol extracts of $B$. mollis against Candida albicans and Candida mycoderma using the agar diffusion assay. The bark extract exhibited activities against Candida mycoderma with zone of inhibition of $3.0 \mathrm{~mm}$
[35]. These antifungal properties of $B$. mollis corroborate the traditional uses of the species against fungal and microbial infections.

\section{Antileishmanial activity}

Bridelia mollis methanol bark extract exhibited weak antileishmanial activity with $\mathrm{IC}_{50}$ value > $200.0 \mu \mathrm{g} / \mathrm{mL}$ against Leishmania amazonensis promastigotes [36]. Bapela et al [14] assessed antileishmanial activities of methanol and dichloromethane root extracts of $B$. mollis against Leishmania donovani. The dichloromethane extracts exhibited inhibitory activities on the growth of amastigote phases of Leishmania donovani with half maximal inhibitory concentration $\left(\mathrm{IC}_{50}\right)$ values of $1.92 \mu \mathrm{g} / \mathrm{mL}$ with selectivity index value of 27 [14]. Bapela et al [39] found that the majority of the non-polar extracts of medicinal herbs used against fever and malaria are characterized by antiplasmodial activities, and therefore, likely to have antileishmanicidal properties as both leishmaniasis and malaria are protozoal infections characterized by similar metabolic systems. Therefore, findings of this research imply that $B$. mollis extracts may have potential as antileishmanial agents.

\section{Antioxidative activity}

Ndhlala et al [37] assessed antioxidant properties of aqueous and methanolic fruit extracts of $B$. mollis using reducing power, superoxide anion radical scavenging effect, 1,1-diphenyl-2picrylhydrazyl (DPPH) radical scavenging assay and the inhibition of phospholipids peroxidation using colorimetric technique. The extracts of pulps and peels of the species demonstrated high antioxidant activities. The authors observed high levels of species extracts exceeding $75 \%$ superoxide anion scavenging, the peel and pulp exhibited excellent capacities to inhibit lipid peroxidation at higher concentrations.

The degree of polymerization was 9.8 monomer units of catechin per polymer of phenolic acid compounds in the peels and pulps of the species [37]. Chauke et al [13] assessed antioxidative properties of acetone leaf extracts of $B$. mollis using the 1,1-diphenyl-2-picrylhydrazyl (DPPH) radical scavenging assay. The extract exhibited dose-dependent activity with $\mathrm{IC}_{50}$ value of 130.0 $\mu \mathrm{g} / \mathrm{mL}$, which was higher than the ascorbic acid, the standard $I_{50}$ value of $25 \mu \mathrm{g} / \mathrm{mL}$ [13]. The documented antioxidant activities of $B$. mollis are probably due to tannins and phenolics that have been isolated from the species [15]. 


\section{Antiplasmodial activity}

Bapela et al [38] assessed antiplasmodial properties of dichloromethane and methane root extracts of $B$. mollis using the $[3 \mathrm{H}]$ hypoxanthine incorporation assay using chloroquine sensitive (NF54) strain of Plasmodium falciparum as the test organism. Both dichloromethane and methane extracts exhibited activity with $\mathrm{IC}_{50}$ values of $3.06 \mu \mathrm{g} / \mathrm{mL}$ and $28.5 \mu \mathrm{g} / \mathrm{mL}$, respectively with selectivity index of 17 , which was considered not to be toxic [38]. These findings corroborate the traditional use of $B$. mollis as traditional medicine against fever and malaria in South Africa [29].

\section{Cytotoxicity activity}

Bridelia mollis methanol bark extract was not cytotoxic to BALB/c mouse macrophages with half maximal cytotoxic concentration $\left(\mathrm{CC}_{50}\right)$ value of $>200 \mu \mathrm{g} / \mathrm{mL}$ [36]. Bapela et al [38] assessed cytotoxicity activities of dichloromethane and methane root extracts of $B$. mollis against mammalian L-6 rat skeletal myoblast cells with podophyllotoxin as a control. Both dichloromethane and methane extracts demonstrated activities with $\mathrm{IC}_{50}$ values of 51.4 $\mu \mathrm{g} / \mathrm{mL}$ and $49.6 \mu \mathrm{g} / \mathrm{mL}$, respectively with selectivity indices value of 16.8 and 24.6, respectively, which were regarded to be nontoxic to rat skeletal myoblast L6 cells [38].

Bapela et al [14] assessed cytotoxicity properties of dichloromethane and methanol leaf extracts of $B$. mollis by assessing the inhibition of mammalian cell growth by cultivating rat skeletal myoblast L6 cells in extracts with concentrations varying from 0.002 to $100.0 \mu \mathrm{g} / \mathrm{mL}$ in 96 well culture plates with podophyllotoxin as a positive control. The methanol and dichloromethane extracts exhibited $\mathrm{IC}_{50}$ values of $49.6 \mu \mathrm{g} / \mathrm{mL}$ and $51.4 \mu \mathrm{g} / \mathrm{mL}$, respectively which were much higher than $\mathrm{IC}_{50}$ value of $0.007 \mu \mathrm{g} / \mathrm{mL}$ exhibited by podophyllotoxin, the control [14].

\section{Nutritional composition of Bridelia mollis leaves and seeds}

Seeds of $B$. mollis have nutrients such as fats and proteins and minerals such as $\mathrm{Cu}, \mathrm{Ca}, \mathrm{Fe}$, $\mathrm{Mn}, \mathrm{Zn}, \mathrm{Mg}$ and $\mathrm{P}$ (Table 2). Aganga et al [12] isolated phenolics from seeds while Chauke et al [13] isolated tannins from leaves of $B$. mollis. Gundidza and Pomerai [15] identified fatty acids such as $\alpha$-linolenic $(41.4 \%)$, trans elaidic (21.4 $\%)$, linoleic (14.7\%), palmitic $(11.5 \%)$ and stearic $(8.3 \%)$ from seeds of $B$. mollis. The essential macronutrients present in $B$. mollis are $\mathrm{Ca}, \mathrm{Mg}$ and $\mathrm{P}$, with $\mathrm{P}$ being a key component of molecular structures such as DNA and RNA, and needed for bone and teeth formation and maintenance in all vertebrates [39]. Calcium is maintained in the bones and required for hormone secretion and muscle contraction while $\mathrm{Mg}$ is important to many major processes such as mineralization of bones, synthesis of proteins, enzyme activities, contraction of muscles, nerve function, immunity, and all energy reactions [40].

Trace element present in $B$. mollis include $\mathrm{Cu}$, $\mathrm{Fe}, \mathrm{Mn}$ and $\mathrm{Zn}$, with $\mathrm{Mn}$ playing an important role for stimulating and activating several enzymes [19]. According to Varzakas et al [19] $\mathrm{Cu}$ is required by the human body in minute quantities as a constituent of redox enzymes while iron is important for hemoglobin formation and oxygen transport with low iron intake and/or bioavailability leading to anemia [41].

Zinc is necessary for the body's enzymatic reactions necessary for cell, protein and DNA synthesis with $\mathrm{Zn}$ deficiency leading to delayed growth, dysentery, disturbed neuropsychological performance, pneumonia, and abnormalities of fetuses [42]. Some fatty acids for example $\alpha$ linolenic are essential for human health as they are characterized by pharmacological properties such as anti-cancer, cardiovascular-protective, anti-inflammatory, neuro-protective, antioxidative and anti-osteoporotic [43]. The phenolic antioxidants which include tannins are known to scavenge radicals in a dose-dependent trend [44]. Bridelia mollis has good nutritive value which support its use as food, fodder and herbal medicine.

\section{CONCLUDING REMARKS}

The present study presents the medicinal uses, pharmacological activities of $B$. mollis, a plant species characterized by nutraceutical and functional food properties. Preliminary pharmacological assessment of the crude extracts of $B$. mollis seems to support the health claims associated with the species. Detailed studies on the phytochemistry, pharmacological and toxicological properties of the species are required in order to establish the real potential benefits of $B$. mollis as a nutraceutical agent. Further in vitro, in vivo and clinical studies are needed to establish the safety and practical uses of the species as a nutraceutical agent that might have beneficial effects on improving human health. 
Table 2: Nutritional and phytochemical composition of leaves and seeds of Bridelia mollis

\begin{tabular}{lllcc}
\hline Nutritional composition & Value & $\begin{array}{l}\text { Plant } \\
\text { part }\end{array}$ & $\begin{array}{c}\text { Reference } \\
\text { Acid neutral detergent (ADF) (g/100g) }\end{array}$ & $\begin{array}{c}\text { Recommended daily } \\
\text { allowance (RDA) }\end{array}$ \\
Ash (\% dry weight) & 10.5 & Seed & 12 & - \\
Ca (g/100g) & 2.4 & Seed & 12 & 1000.0 \\
Crude fat (\% dry weight) & 0.31 & Seed & 12 & 300.0 \\
Crude protein (\% dry weight) & 2.6 & Seed & 12 & 34.0 \\
Cu (mg/100g) & 21.7 & Seed & 12 & 0.9 \\
Dry matter (\%) & 9.0 & Seed & 12 & - \\
Fe (mg/100g) & 97.0 & Seed & 12 & -18.0 \\
In vitro true dry matter digestibility (IVTD) (g/100g) & 95.1 & Seed & 12 & - \\
Mg (g/100g) & 0.10 & Seed & 12 & $320.0-420.0$ \\
Mn (mg/100g) & 41 & Seed & 12 & - \\
Neutral detergent fibre (NDF) (\%) & 55.1 & Seed & 12 & - \\
Phenolic (gallic acid equivalent mg/ml) & 39.31 & Leaf & 13 & 700.0 \\
P (g/100g) & 0.37 & Seed & 12 & - \\
Tannins (mg/ml gallic acid equivalent) & 5.97 & Seed & 12 & $8.0-11.0$ \\
Zn (mg/100g) & 0.17 & Seed & 12 & - \\
Fatty acids & & & & - \\
a-Linolenic acid (\%) & 41.4 & Seed & 15 & - \\
Trans elaidic (\%) & 21.4 & Seed & 15 & - \\
Linoleic acid (\%) & 14.7 & Seed & 15 & - \\
Palmitic (\%) & 11.5 & Seed & 15 & \\
Stearic (\%) & 8.3 & Seed & 15 & \\
\hline
\end{tabular}

\section{DECLARATIONS}

\section{Acknowledgement}

The author would like to express his gratitude to the National Research Foundation, South Africa and Govan Mbeki Research and Development Centre, University of Fort Hare for financial support to conduct this study.

\section{Conflict of Interest}

No conflict of interest associated with this work.

\section{Contribution of Authors}

The authors declare that this work was done by the authors named in this article and all liabilities pertaining to claims relating to the content of this article will be borne by them.

\section{REFERENCES}

1. Palgrave KC. Keith Coates Palgrave Trees of Southern Africa. Struik Publisher, Cape Town, 2002.

2. Hyde MA, Wursten BT, Ballings $P$, Coates Palgrave $M$. Flora of Zimbabwe: Species information: Bridelia mollis Hutch; 2018.2 Available on: https://www.zimbabweflora.co.zw/speciesdata/species.p hp?species_id=134710, retrieved 13 January 2018.

3. Palmer E, Pitman P. Trees for southern Africa covering all known indigenous species in Republic of South Africa, South West Africa, Botswana, Lesotho and Swaziland. A.A. Balkema, Cape Town; 1972.
4. McGregor J. Woodland resources: ecology, policy and ideology, a historical case study of woodland use in Shurugwi communal area, Zimbabwe. PhD thesis, Loughborough University, Loughborough; 1991; p. 479.

5. Sullivan S. People, plants and practice in drylands: sociopolitical and ecological dimensions of resource-use by Damara farmers in north-west Namibia. PhD thesis. University College London, London; 1998; p. 363.

6. Van Wyk B, Gericke, N. People's plants: a guide to useful plants of southern Africa. Briza Publications, Pretoria; 2007.

7. Nhancale CC. Participatory governance for sustainable management of natural resources in the Great Limpopo Transfrontier Park: the case of Parque Nacional do Limpopo, Moçambique. MSc dissertation, University of Stellenbosch, Cape Town; 2007; p. 171.

8. Mothanka DMT, Motlhanka $P$, Selebatso T. Edible indigenous wild fruit plants of eastern Botswana. Int $J$ Poultry Sci 2008; 7(5): 457-460.

9. Maroyi $A$. The gathering and consumption of wild edible plants in Nhema communal area, Midlands province, Zimbabwe. Ecol Food Nutr 2011; 50: 506-525.

10. Van Wyk B-E. The potential of South African plants in the development of new food and beverage products. S. Afr J Bot 2011; 77: 857-868.

11. Scoones I. Browse ranking in Zimbabwe. RRA Notes 1994; 20: 91-94.

12. Aganga AA, Adogla-Bessa T, Omphile UJ, Tshireletso $K$. Significance of browses in the nutrition of Tswana goats. Arch Zootec 2000; 49: 469-480.

13. Chauke AM, Shai LJ, Mphahlele PM, Mogale MA. Radical scavenging activity of selected medicinal plants from Limpopo province of South Africa. Afr J Tradit Complem Altern Med 2012; 9(3): 426-430. 
14. Bapela MJ, Kaiser M, Meyer JJM. Antileishmanial activity of selected South African plant species. S Afr J Bot 2017; 108: 342-345.

15. Gundidza M, Pomerai M. Physicochemical characterisation and essential fatty acid profiling of a fixed oil extracted from Bridelia mollis seeds. The 2nd international conference on pesticidal plants, 6-9 February 2017, The Elephant Hills Resort, Victoria Falls, Zimbabwe.

16. Rivera G, Bocanegra-García V, Monge A. Traditional plants as source of functional foods: a review. Cyta $J$ Food 2010; 8(2): 159-167.

17. Chauhan B, Kumar G, Kalam N, and Ansari SH. 2013. Current concepts and prospects of herbal nutraceutical: a review. J Adv Pharm Technol Res 2013; 4(1): 4-8.

18. González-Sarrías A, Larrosa M, García-Conesa MT, Francisco A, Barberán T, Espín JC. Nutraceuticals for older people: Facts, fictions and gaps in knowledge. Maturitas 2013; 75: 313-334.

19. Varzakas T, Zakynthinos G, Verpoort F. Plant food residues as a source of nutraceuticals and functional foods. Foods 2016; 5: 88.

20. Schmidt E, Lotter M, McCleland W. Trees and shrubs of Mpumalanga and Kruger National Park. Jacana Media, Johannesburg; 2002.

21. Maroyi A. Ethnopharmacology and therapeutic value of Bridelia micrantha (Hochst.) Baill. in tropical Africa: a comprehensive review. Molecules 2017; 22: 1493.

22. Setshogo MP, Venter F. Trees of Botswana: names and distribution. Southern African Botanical Diversity Network Report No. 18. Pretoria; 2003; $p 162$.

23. Hoffmann $P$, Kathriarachchi $H$, Wurdack KJ. A phylogenetic classification of Phyllanthaceae (Malpighiales: Euphorbiaceae sensu lato). Kew Bull 2006; 61: 37-53.

24. Smith AR. Euphorbaceae. In: Polhill RM (Ed.), Flora of tropical East Africa. Rotterdam: AA Balkema; 1987; pp. 1-407.

25. Ngueyem TA, Brusotti G, Caccialanza G, Finzi PV. The genus Bridelia: a phytochemical and ethnopharmacological review. J Ethnopharmacol 2009; 12: 339-349.

26. van Wyk B-E, van Wyk P. Field guide to trees of southern Africa. Struik, Cape Town; 1997.

27. Hedberg I, Staugård F. Traditional medicine in Botswana: Traditional medicinal plants. Ipelegeng Publishers, Gaborone; 1989.

28. Mabogo DEN. The ethnobotany of the Vhavenda. MSc dissertation, University of Pretoria, Pretoria; 1990; $p$ 260.

29. Bapela MJ. NMR-based metabolomic study of medicinal plants used against malaria and the isolation of bioactive alkaloids. PhD thesis, University of Pretoria, Pretoria; 2016; p. 159.

30. Arnold H-J, and Gulumian M. Pharmacopoeia of traditional medicine in Venda. J Ethnopharmacol 1984; 12: $35-74$.
31. Maroyi A. Ethnobotanical study of medicinal plants used by people in Nhema communal area, Zimbabwe. J Ethnopharmacol 2011; 136: 347-354.

32. Mbayo KM, Kalonda ME, Tshisand TP, Kisimba KE, Mulamba M, Richard MK, Sangwa KG, Mbayo KG, Maseho MF, Bakari S, Mpiana TP, Kahumba BJ, Lumbu, S.J-B. Contribution to ethnobotanical knowledge of some Euphorbiaceae used in traditional medicine in Lubumbashi and its surroundings (DRC). J Adv Bot Zool 2016; 4(2): 1-16.

33. Shai LJ, Chauke MA, Magano SR, Mogale AM, Eloff JN. Antibacterial activity of sixteen plant species from Phalaborwa, Limpopo province, South Africa. J Med PI Res 2013; 7: 1899-1906.

34. Samie A, Tambani $T$, Harshfield $E$, Green $E$, Ramalivhana JN, Bessong PO. Antifungal activities of selected Venda medicinal plants against Candida albicans, Candida krusei and Cryptococcus neoformans isolated from South African AIDS patients. Afr $J$ Biotechnol 2010; 9: 2965-2976.

35. Mukanganyama S, Ntumy AN, Maher F, Muzila M, Andrae-Marobela $K$. Screening for anti-infective properties of selected medicinal plants from Botswana. Afr J PI Sci Biotechnol 2011; 5(1): 1-7.

36. Monzote L, Piñón A, Setzer WN. Antileishmanial potential of tropical rainforest plant extracts. Medicines 2014; 1 : 32-55.

37. Ndhlala AR, Mupure C, Chitindingu K, Benhura MA, Muchuweti M. Antioxidant potentials and degrees of polymerization of six wild fruits. Scientific Res Essay 2006; 1: 87-92.

38. Bapela MJ, Meyer JJM, Kaiser M. In vitro antiplasmodial screening of ethnopharmacologically selected South African plant species used for the treatment of malaria. $J$ Ethnopharmacol 2014; 156: 370-373.

39. Childers DL, Corman J, Edwards M, Elser JJ. 2011. Sustainability challenges of phosphorus and food: solutions from closing the human phosphorus cycle. BioSci 2011; 61(2): 117-124.

40. Glasdam S-M, Glasdam S, Peters GH. The importance of magnesium in the human body: a systematic literature review. Adv Clinical Chem 2016; 73: 169-193

41. Abbaspour N, Hurrell R, Kelishadi R. Review on iron and its importance for human health. J Res Med Sci 2014; 19(2): 164-174.

42. Bhowmik D, Chiranji KP, Kumar S. A potential medicinal importance of zinc in human health and chronic disease. Int J Pharm Biomed Sci 2010; 1(1): 5-11.

43. Kim K-B, Nam YA, Kim HS, Hayes AW, Lee B-M. $\alpha$ linolenic acid: nutraceutical, pharmacological and toxicological evaluation. Food Chem Toxicol 2014; 70 : 163-178.

44. Repetto MG, Llesuy SF. Antioxidant properties of natural compounds used in popular medicine for gastric ulcers. Brazilian J Med Biol Res 2002; 35: 523-534. 